
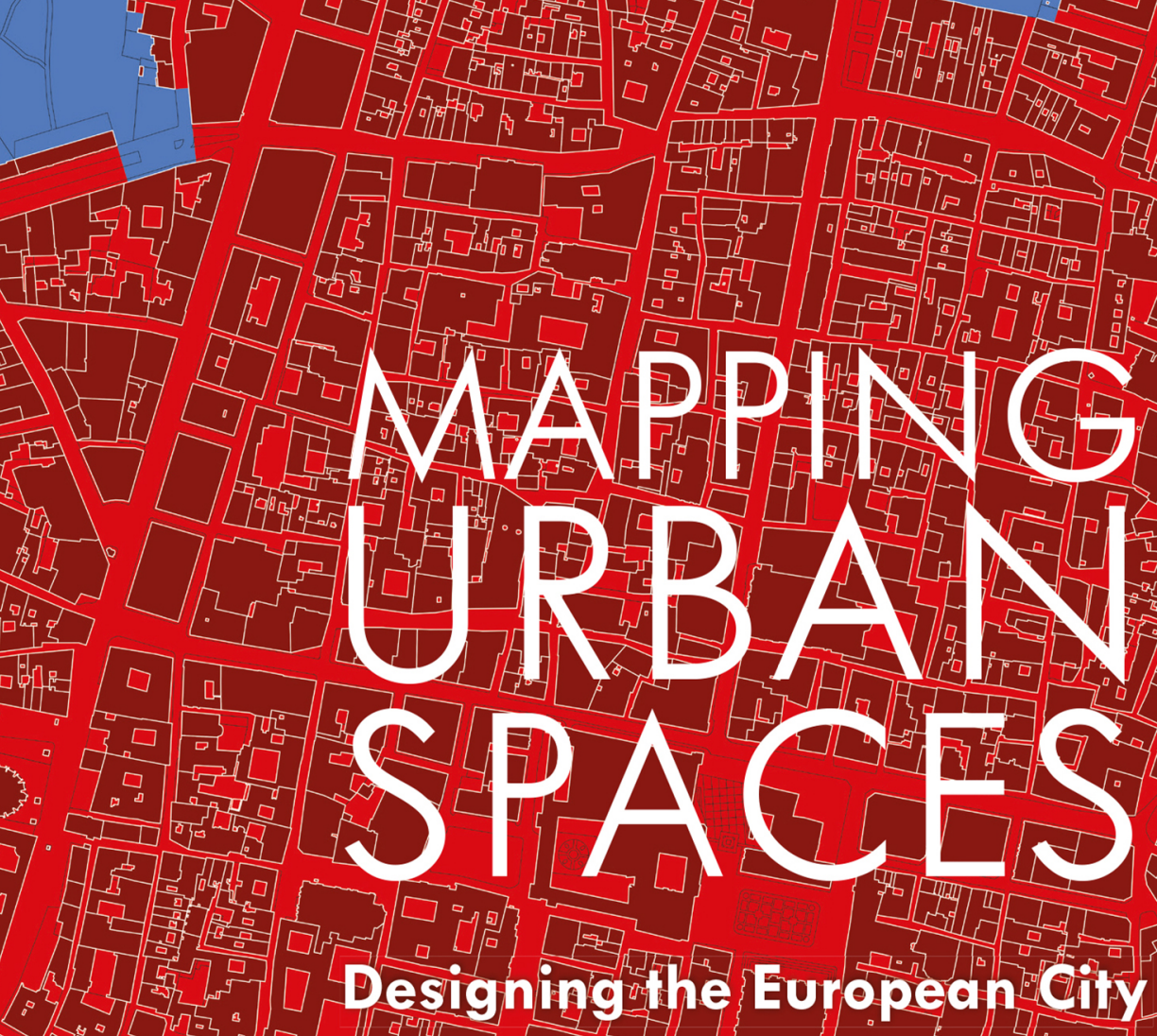

Edited by

Lamberto Amistadi, Valterabalducci, Tomasz Bradecki, Enrico Prandi, and Uwe Schrö dèr

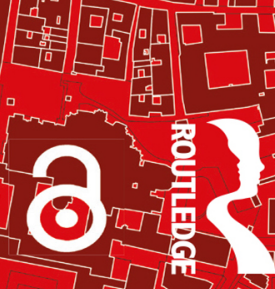




\section{MAPPING URBAN SPACES}

Mapping Urban Spaces focuses on medium-sized European cities and more specifically on their open spaces from psychological, sociological, and aesthetic points of view. The chapters illustrate how the characteristics that make life in medium-sized European cities pleasant and sustainable - accessibility, ease of travel, urban sustainability, social inclusiveness - can be traced back to the nature of that space.

The chapters develop from a phenomenological study of space to contributions on places and landscapes in the city. Centralities and their meaning are studied, as well as the social space and its complexity. The contributions focus on history and theory as well as concrete research and mapping approaches and the resulting design applications.

The case studies come from countries around Europe including Poland, Italy, Greece, Germany, and France, among others. The book will be of interest to students, scholars, and practitioners in architecture, urban planning, and landscape architecture.

Lamberto Amistadi is an architect and an associate professor in the Department of Architecture at the University of Bologna - Cesena Campus and the coordinator of the ArchéA program. He is the deputy director of the scientific journal FAMagazine, devoted to research and projects concerning architecture and the city, and co-director of the series TECA, Teorie della Composizione architettonica (Naples: Clean). Along with Ildebrando Clemente, he founded and directs the series SOUNDINGS: Theory and Architectural Openness (Florence: Aión), which has included monographic volumes on John Hejduk and Aldo Rossi. He is also the author of numerous publications.

Valter Balducci is an architect, has a PhD in architecture (IUAV, 1994), and is a professor at the École Nationale Supérieure d'Architecture of Normandie, Rouen-Darnétal. He has been a teacher in the Faculty of Architecture at the Genua University (1990-2000), and a researcher and assistant professor at the Bologna University (2001-2014). Since 2014, he is a full professor in urban design at ENSA of Normandie. His major research interests are focused on urban analysis and history. Since 2003, he has been conducting research on seaside tourism and projects on public space within seaside territories in relation to climate change. 
Tomasz Bradecki, $\mathrm{PhD}$, is an architect, a researcher, and a lecturer of architecture and urban design in the Department of Urban and Spatial Planning, Faculty of Architecture, Silesian University of Technology since 2010. His main fields of interest include housing, urban design, and mapping with models. Besides research and teaching activity, he has been running an architectural firm since 2008. He is a member of the Polish Chamber of Architects. He is an author and co-author of many publications focusing on housing, commercial, and urban projects.

Enrico Prandi is an architect and an associate professor at the Department of Engineering and Architecture of the University of Parma and the coordinator of the Parma group of the ArchéA program. He is the director of the scientific open access e-journal FAMagazine. He has been contributing to various research projects concerning architecture and the city and is co-director of the series AAC - Arts | Architecture | City (Turin: Accademia University Press). Since 2016, he has been the coordinator of the research project conducted by architect Luigi Vietti at the CSAC - Study Center and Communication Archive. He is also the author of numerous publications.

Uwe Schröder is an architect and a professor at the RWTH Aachen University. In 1993, he founded his architectural office in Bonn, and since then, he has devoted himself to the theory and practice of architecture. Between 2004 and 2008, he was an ordinary professor of architectural theory and design at the TH Köln, and since 2008, he has been a professor in the Department of Spatial Design in the Faculty of Architecture at RWTH Aachen University. Besides his research and teaching activity in Germany, he taught as a visiting professor at various Italian universities, including Bologna, Naples, Bari, Catania, Milan, and Parma. 


\section{MAPPING URBAN SPACES \\ Designing the European City}

Edited by Lamberto Amistadi, Valter Balducci, Tomasz Bradecki, Enrico Prandi, and Uwe Schröder 
First published 2022

by Routledge

605 Third Avenue, New York, NY 10158

and by Routledge

2 Park Square, Milton Park, Abingdon, Oxon, OX14 4RN

Routledge is an imprint of the Taylor \& Francis Group, an informa business

(C) 2022 selection and editorial matter, Lamberto Amistadi, Valter Balducci, Tomasz Bradecki, Enrico Prandi, and Uwe Schröder; individual chapters, the contributors

The right of Lamberto Amistadi, Valter Balducci, Tomasz Bradecki, Enrico Prandi, and Uwe Schröder to be identified as the authors of the editorial material, and of the authors for their individual chapters, has been asserted in accordance with sections 77 and 78 of the Copyright, Designs and Patents Act 1988.

This Research is produced under the Erasmus + Strategic Partnership for higher education Programme. Project Reference: 2018-1-IT02-KA203-048305.

The Open Access version of this book, available at www.taylorfrancis.com, has been made available under a Creative Commons Attribution-Non Commercial 4.0 license.

Trademark notice: Product or corporate names may be trademarks or registered trademarks, and are used only for identification and explanation without intent to infringe.

Library of Congress Cataloging-in-Publication Data

Names: Amistadi, Lamberto, editor. | Balducci, Valter, editor. | Bradecki,

Tomasz, 1979- editor. | Prandi, Enrico, editor. Schröder, Uwe, 1964- editor.

Title: Mapping urban spaces: designing the European city / edited by

Lamberto Amistadi, Valter Balducci, Tomasz Bradecki,

Enrico Prandi and Uwe Schröder.

Description: New York, NY: Routledge, 2022. | Includes bibliographical

references and index.

Identifiers: LCCN 2021009841 (print) | LCCN 2021009842 (ebook) |

ISBN 9781032041261 (hardback) | ISBN 9781032041247 (paperback) |

ISBN 9781003190660 (ebook)

Subjects: LCSH: City planning-Europe. | Open spaces-Europe. |

Architecture and society-Europe.

Classification: LCC HT169.E8 M36 2022 (print) | LCC HT169.E8 (ebook) |

DDC 307.1/216094-dc23

LC record available at https://lccn.loc.gov/2021009841

LC ebook record available at https://lccn.loc.gov/2021009842

ISBN: 9781032041261 (hbk)

ISBN: 9781032041247 (pbk)

ISBN: 9781003190660 (ebk)

Typeset in Bembo

by codeMantra
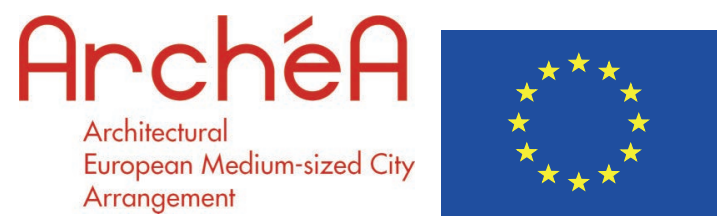

Co-funded by the Erasmus+ Programme of the European Union 


\section{CONTENTS}

\section{INTRODUCTION}

The ArchéA Method

Lamberto Amistadi

\section{PART I}

Mapping Spaces: The Phenomenological Approach to the City of Spaces

1 A Spatial Understanding of Architecture and the City Uwe Schröder

2 Landmarks in a History of Spatial Mapping Felix Mayer

3 The Many-Faceted Notion of Space: On the Hypothesis of Mapping and the Observation of Spatial Phenomena

Sarah Maria Schroeter

4 Stadtraumgestaltungen: On Perceiving and Reading Urban Spaces Timo Steinmann

5 Where the Compact and Open City Meet: Inner and Outer Spaces on the Periphery of Aachen North 
6 Here and There: On the Ambivalence of Transitional Spaces

Franziska Kramer

\section{PART II}

Mapping Places: The Italian Tradition of Urban Studies

7 Drawing the City: Form and Meaning

Lamberto Amistadi

8 Urban Events and the Soul of the City: The Poetic Political

Tripartition of Urban Form

Ildebrando Clemente

9 Civic Urbanity: The Places of Everyday Life

Francesco Saverio Fera

10 Venice as a Paradigm: Urban Studies and the Value of Emptiness in the City's Design

Giovanni Marras

11 Nature Prepares the Sites, But It Is Man Who Creates the Organism: Bologna through Its Geography, Its History, and Its Planning Tools

Valentina Orioli

12 New Urban Landscapes: Fragments of Civil Architecture

Gino Malacarne

PART III

Mapping Natural Space: Greenspaces and Urban Design

13 The Role of Greenspaces in Urban Design Theories in France Valter Balducci

14 Greenspace as an Element for a New Urban Dynamic Fabienne Fendrich

15 Uses of Mapping: Methods of Investigation and Ways of Narrating Territory in Architectural Practice and Teaching Anne Portnoï 
16 Towards a More "Natural" City?

\section{PART IV}

\section{Mapping Centralities: Urban Regeneration toward a} Polycentric City

17 The Long-Term Method of the Urban Project in Italy and the Parma School

Carlo Quintelli

18 Designing the European Medium-Sized City: Urban Regeneration Technique through the Structured Densification of the Centrality System

Enrico Prandi

19 The Project of a Metropolitan Urban Centrality: The Case of the Former Fruit and Vegetable Market of Bologna

Paolo Strina

20 Densification as the Key to Suburb Regeneration: The Case of Driescher Hof in Aachen

Giuseppe Verterame

21 The European Medium-Sized City: The Characteristics of the Urban Form

Marco Maretto

22 The Idea of Space and Urban Sequences: The Case of Parma Carlo Gandolfi

\section{PART V}

\section{Mapping Social Space: Demographic Analysis as an Image of} Urban Complexity

23 Mapping Urban Spaces with the Use of Physical, Digital, and Augmented Reality Models: Experiences from Applications in Architectural and Urban Education 
viii Contents

24 The Urban Circle of Life of People with Disabilities: Mapping Urban Inconveniences

Katarzyna Ujma-Wasowicz

25 Multigenerational Spaces in Conceptual Urban Projects in Polish Cities

Agnieszka Labus and Pawet Woźnicki

\section{AFTERWORD}

Problems of the Contemporary City

Raffaella Neri

Index 


\section{CONTRIBUTORS}

Lamberto Amistadi is a professor of architecture and urban design, Department of Architecture, University of Bologna - Cesena Campus.

Valter Balducci is a full professor of urban design at the École Nationale Supérieure d'Architecture of Normandie, Rouen-Darnétal, and a member of the ATE Research Laboratory.

Jean-Marc Bichat is an associate professor of architecture at the École Nationale Supérieure d'Architecture of Paris Val de Seine.

Tomasz Bradecki, PhD, is a researcher and a lecturer of architecture and urban design at the Department of Urban and spatial Planning, Faculty of Architecture, Silesian University of Technology.

Philippe Chavanes is an associate professor of architecture at the École Nationale Supérieure d'Architecture of Paris la Villette.

Ildebrando Clemente is a professor of architecture and urban design, Department of Architecture, University of Bologna - Cesena Campus.

Fabienne Fendrich is a state architect, landscaper, and a project manager in "Innovation and Experimentation" at the French Ministry of Culture.

Francesco Saverio Fera is a professor of architecture and urban design, Department of Architecture, University of Bologna - Cesena Campus.

Carlo Gandolfi is a researcher of architecture and urban design, Department of Engineering and Architecture, University of Parma. 
Franziska Kramer is a lecturer at the Department of Spatial Design, Faculty of Architecture, RWTH Aachen University.

Agnieszka Labus is an assistant professor at the Faculty of Architecture, Department of Urban and Spatial Planning, Silesian University of Technology.

Gino Malacarne is a professor of architecture and urban design, Department of Architecture, University of Bologna - Cesena Campus.

Marco Maretto is a professor of architecture and urban design, Department of Engineering and Architecture, University of Parma.

Giovanni Marras is a professor of architecture and urban design, Department of Architecture and Arts, IUAV University of Venice.

Felix Mayer is a teaching assistant and researcher at the Department of Spatial Design, Faculty of Architecture, RWTH Aachen University.

Raffaella Neri is professor of architecture and urban design, ABC Department-Architecture, Built Environment and Construction Engineering, Politecnico di Milano.

Valentina Orioli is a professor of urban planning, Department of Architecture, University of Bologna - Cesena Campus.

Anne Portnoï is an associate professor of architecture at the École Nationale Supérieure d'Architecture of Paris la Villette, and a member of the AHTTEP Research Laboratory.

Enrico Prandi is a professor of architecture and urban design, Department of Engineering and Architecture, University of Parma.

Carlo Quintelli is a professor of architecture and urban design, Department of Engineering and Architecture, University of Parma.

Uwe Schröder is a professor of architecture at the Department of Spatial Design, Faculty of Architecture, RWTH Aachen University.

Sarah Maria Schroeter is a student assistant at the Department of Spatial Design, Faculty of Architecture, RWTH Aachen University.

Timo Steinmann is a lecturer at the Department of Spatial Design, Faculty of Architecture, RWTH Aachen University.

Paolo Strina is a PhD in architecture and urban design, Department of Engineering and Architecture, University of Parma. 
Katarzyna Ujma-Wassowicz is a professor at the Silesian University of Technology at the Faculty of Architecture, Gliwice, Poland.

Giuseppe Verterame is a $\mathrm{PhD}$ scholar in architecture and urban design, Department of Engineering and Architecture, University of Parma.

Paweł Woźnicki has an MA in urban and regional studies from the Center for European Regional and Local Studies (EUROREG).

Ilaria Maria Zedda is a lecturer at the Department of Spatial Design, Faculty of Architecture, RWTH Aachen University. 


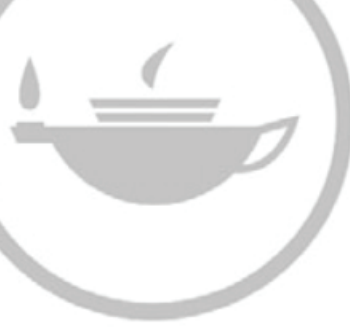

Taylor \& Francis
Taylor \& Francis Group http://taylorandfrancis.com 


\section{0}

\section{VENICE AS A PARADIGM}

\section{Urban Studies and the Value of Emptiness in the City's Design}

\section{Giovanni Marras}

This chapter will focus on the value of emptiness and the instrumental role of urban studies in architectural design, critically reconsidering certain modes of interpreting the city which matured starting from research on the urban form of Venice.

Venice as a text, a pretext or, simply, a place of choice - a royal city of stone and brick made of built islands but also an ideal city made of paper, a vision of the mind's eye of architects, geographers, writers, art historians, and philosophers.

Venice as a paradigm to be questioned and a pretext for a "Venetian" approach to the architectural project that is intertwined with the events of the Royal Higher Institute of Architecture, the second school of architecture in Italy after that of Rome, inaugurated in Venice in November 1934.

For a certain Italian architectural culture, the city and the landscape were the foundation of a design approach based on the relationship between urban morphology and building typology.

Text, context, pretext, are terms that have had a significant weight for the Italian architectural culture of the last century, and in the context of a daily theoretical elaboration, have been recoded and agreed over and over again and have assumed relevance also in the international context.

\section{The School of Venice}

Building the city starting from a "scientific" knowledge of the city was the hallmark of a certain design approach that

Does not call into question the neon, the ephemeral and the fast, but wants to reaffirm the secular substance of architecture, the importance of looking at certain characteristics of the past and not claiming [...] to give rise to what is suitable for our time only from a preconceived opposition to the past, or from an equally preconceived ideology of the past $[\ldots]$. 
Experiments, studies, and research that can be traced back to "a particularly intense creative moment at the University Institute of Venice" (Tentori 1994, 8) that Francesco Tentori referencing the more well-known Learning from Las Vegas - identified with the motto Learning from Venice.

The teaching at the Higher Institute of Architecture in Venice initially leaned toward a certain architectural traditionalism typical of the cultural environment of the academy of fine arts from which it originated but began to undergo a progressive and inexorable change in cultural orientation under the lengthy direction of Giuseppe Samonà.

Giuseppe Samonà was born in Palermo, Sicily in 1898 and studied engineering. He opened the 1945/1946 academic year (his first year as the Institute's director and the first after Italy's liberation) with a "report" in which he established the start of a renewal based on the conviction that "Every architectural theme [...] to have deep roots in life, always requires a deep investigation of the environment, a social investigation that must be analytically extended with meticulous care" (Samonà 1946, 4). In the same speech, taking leave of his predecessor Guido Cirilli, Samonà enunciates the key words of a new "revolutionary" didactic approach between the lines:

Maestro of living stones, an expert in solid masonry, a perfect marble cutter [...] As a Maestro he knew how to give the School the best of himself; rather than cultural problems he spoke of the living technique of matter, of walls, of proportions. He materially preferred to draw on the pupil's tablet to concretely show how to make architecture with marks rather than with words.

(Samonà 1946, 4)

Marks and words, in antinomian contrast, will instead be the characterizing trait of a new way of conceiving the study of architecture.

Trincanato wrote, "Samonà began to revolutionize this academic method, giving lectures on 'something' that was not, however, remotely the history of art, but the history of the architectural object [...] a teaching of architecture 'touched with the hand' [...] object by object [...] Direct surveys were carried out while he demonstrated, through these lectures, the value of the unity of a building from the point of view of the urban scene [...] It was absolutely not art history [...] it was really a study of the architectural organism" (Trincanato 1997) in the city of Venice.

A way of understanding the study of architecture in which, yes, "technique is [...] the foundation of even more spiritual and poetic disciplines such as composition" (Samonà $1950,1)$ but with a markedly different accentuation from those "technicalities" and "functionalisms" of that sort of "new academy" that was being formed in those years in the international arena. Even before coming to Venice in 1935, with the book La casa popolare degli anni '30 [Social housing of the 1930s] (Samonà 1973), Giuseppe Samonà distanced himself from a certain "internationalism," highlighting the abstract and theoretical character of research on rational housing, with respect to the problem of social housing in the context of the urban transformations of the present.

The re-foundation and cultural renewal of the University of Architecture of Venice therefore started from the real city. In fact, the training of the architect-student had to be marked by 
a greater contact with life, with the problems arising in the center and in the region where [they] carry out their studies [and] the disciplines [...] must be made less abstract by testing their instrumental power on real everyday building problems.

(Samonà 1950, 4)

Giuseppe Samonà gave an opening lecture for the 1953 academic year entitled, "Need for a study of Venice for the urban planning of its modern needs" (Samonà 1978) in which he reiterated the importance of a single theme for composition courses, with the objective of offering a study of the city, in view of the drafting of the new urban plan.

Ignazio Gardella confirms that this point of view was also reflected in the "enrollment policy" (Zucconi and Carraro 2011, 14) of IUAV, where Giuseppe Samonà wanted "educated professionals" (Monestiroli 1997, 71) to teach composition: Franco Albini, Ludovico Barbiano di Belgiojoso, and Ignazio Gardella himself, and Giovanni Astengo for urban planning and Bruno Zevi for history.

Venice, the lagoon, and its hinterland would be the living laboratory in which IUAV took shape as "something new and in any case different, compared to the traditional conflict between the Beaux Arts side and that based on a physical and mathematical approach" (Zucconi and Carraro 2011, 17) or rather a way of understanding the design as being capable of measuring up with the city in its context of large-scale relations, contemplating loans and contaminations with other disciplines: philosophy, geography, literature, economics, anthropology, and so on.

A slow process of re-founding the School destined to settle into a "tradition" of studies and research which, beyond Venice understood as the starting and ending point of the teaching and planning action of teachers and students, was destined to spread in a wider context as a cultural approach to architectural design based on the knowledge of the city and the landscape.

\section{Venice as a Paradigm}

With its complex inlay of islands and canals surrounded by water and lagoon coasts, the bird's eye view of Venice carved on pear wood boards by Jacopo De Barbari in 1500 was for Egle Renata Trincanato the certain body on which to verify a first hypothesis of the nuclear morphogenesis of Venice which, based on a meticulous analysis of the urban morphology of that Venezia Minore [Venice Minor] that in the "planimetric scheme [...] still reflects a large part of the ancient spatial configuration" (Trincanato 1948, 35), highlights the island matrix of the city drawn by the water and built for the subsequent interments of the emerged lands and sandbanks. The large layout of the typical plans of Venice presents an inexhaustible sequence of ways of transforming the boundary between land and water into architecture. Yet in the extreme variability of the modes, it seems possible to identify constants in that "densely structured magma of wrinkled matter with certain emergences" (Samonà 1970, 9) in which the mixtilinear course of the entirely built single islands, while obeying rigorous principles, nevertheless escapes the Cartesian stiffness of the right angle. In the same way, the great "empty spaces" of Venice (the fields), which are the result of a process of building the islands that consolidate starting from the edges, are affected by that liquid matrix underlying the city (Figures 10.1 and 10.2). 


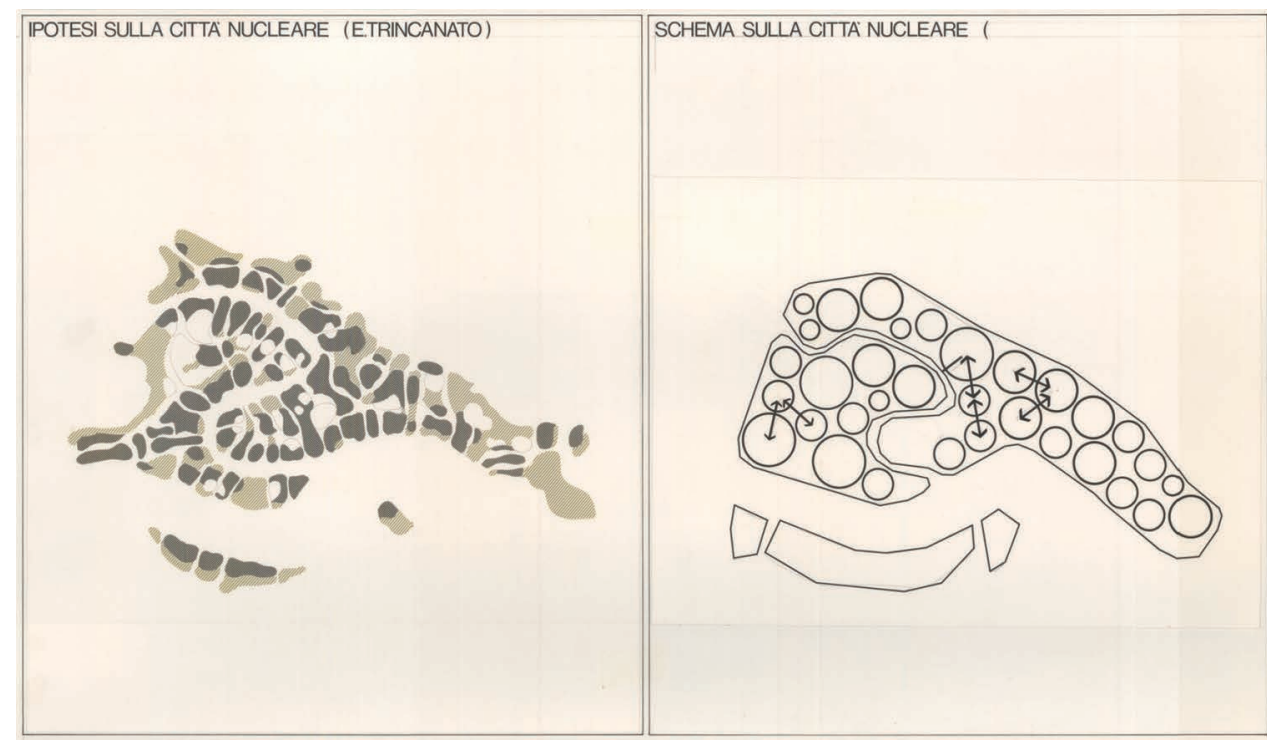

FIGURE 10.1 E. R. Trincanato, Hypothesis on the nuclear city, s.d., Projects Archive - IUAV University of Venice, E. R. Trincanato Collection.

Saverio Muratori, who came to IUAV in 1950 with the students of the distributive character courses of buildings, also attempted to decipher the settlement phases of the morphological structure of the Venetian insulae in relation to the typological invariance of the artifacts. But for Muratori, Venice was above all a pretext for focusing on "a conception [...] of the type and of the building fabric as an organism and of the urban environment as a work of art" (Muratori 1960, 7). Using analysis tools, Muratori intended to penetrate the "mechanisms" of the city's growth, understood in "its integrity and totality of living and operating fabric" (Muratori 1960, 8), on which one can only consciously insert himself. Insula after insula, Muratori consolidated this awareness through "that genetic and historical knowledge of efficient realities [...] with which to collaborate" (Muratori 1960, 8), using design tools to reproduce in vitro those generative processes studied from reality. As proof of the breadth and operational value of such a cultural orientation, Muratori cited a "planning activity conducted in parallel with these studies" and precisely the

winning project of the Competition for the new C.E.P. District, for the urban expansion of Venice on the inner lagoon coast where the functional principles adopted experimented with the current insertion in the historical environmental framework with undeniable success after competing technical attempts.

(Muratori 1960, 8)

Given that for Muratori, "Historical judgment is therefore already operational judgment, an action plan, urban plan and [...] history is doubly necessary as information and as education in the formative values of reality" (Muratori 1960, 10), however, the redundancy of the 


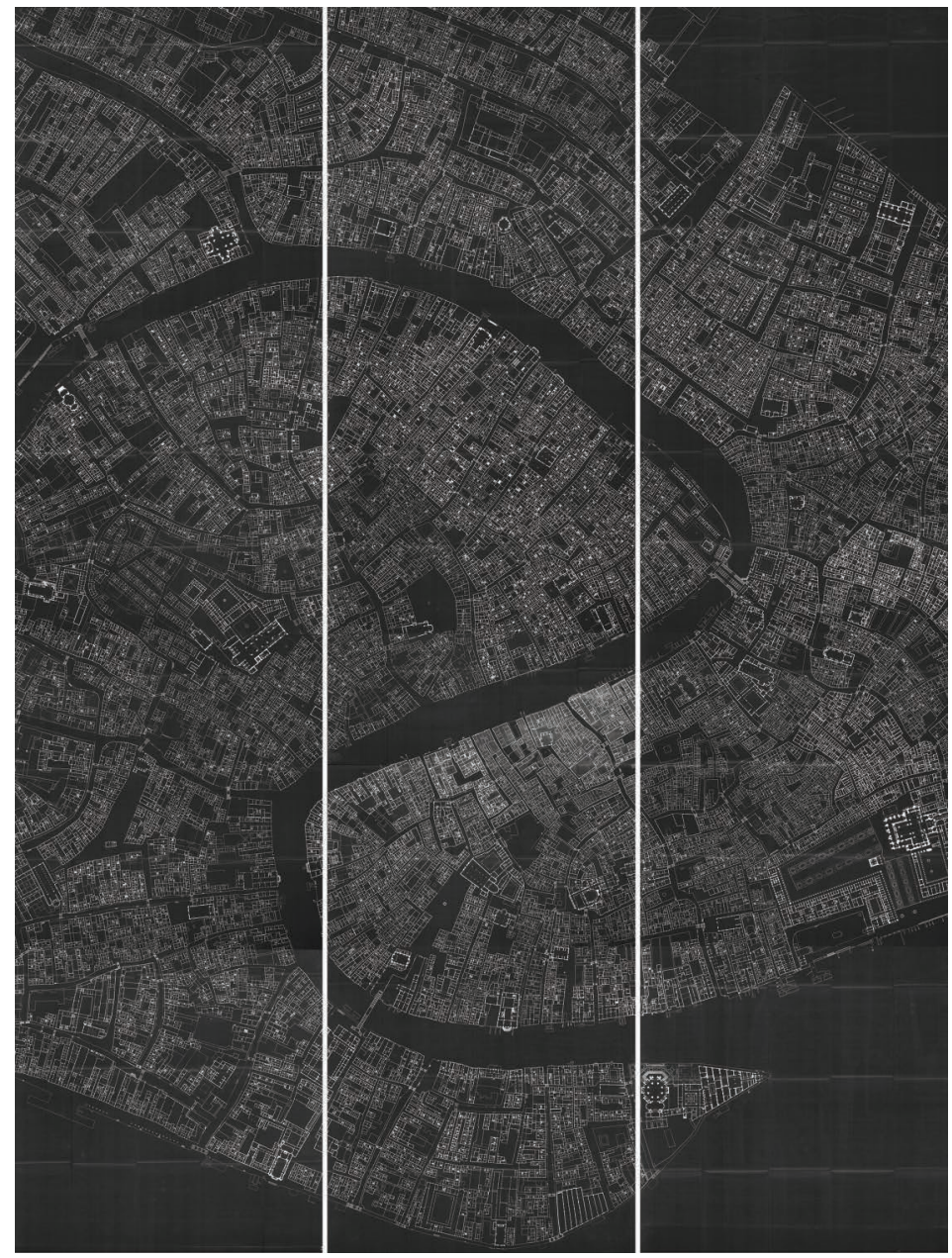

FIGURE 10.2 Venice, Graphic reworking starting from the Venice standard floor plan, 1989, City of Venice, Town Planning Department.

three settlement hypotheses presented in the competition remains inexplicable, highlighting a misunderstood generative automatism between urban analysis and architectural design.

A productive season of research on urban morphology, which coincided with a particularly intense first phase of construction of IUAV, was followed by an equally intense season of design competitions on Venice in the second postwar period that alternatively involved as competitors and/or as jurors a conspicuous number of the School's teachers: the Competition of ideas for the General Town Plan, 1957; the aforementioned Competition for the CEP District at Barene di San Giuliano, 1959 and that for the New Hospital of Venice to be built at the gates of the island city, 1963; the International Competition for the drafting of the urban volumetric plan for the Nuova Sacca del Tronchetto, 1964. The events of these competitions, which intertwined with those of the School for various reasons, were widely echoed in the pages of the magazines of the time, fueling the debate on the inclusion of modern architecture in "historic centers." 


\section{Urban Studies as a Tool, Emptiness as a Value}

The project for the New Hospital of Venice, characterized by the motto Tadzio and presented by the pupils ${ }^{1}$ of Giuseppe Samonà - who received "the implicit solemn commendation of 'citation' from the subsequent design by Le Corbusier" (Tentori 1994, 21) - and that for the Nuova Tronchetto island, distinguished by the motto NOVISSIME, signed by Samonà himself as group leader, ${ }^{2}$ express a considerably different point of view with respect to the strategies implemented by Muratori (Figures 10.3-10.5).

In both projects, "knowledge in terms of geography and urban morphology of the city structure" (Samonà et al. 1964, 11), rather than determining the morphogenetic development of the city by orienting its growth, highlights emptiness as an "essential factor of the city's character" (Piccinato et al. 1965) and as a contrasting element of instrumental value in highlighting the new architectures and the constituent parts of the historic city with their own identity.

In particular, the NOVISSIME project awarded a special mention in the competition for its explosive character - as the juror Astengo defined it - from a "strictly cultural point of view [...] radically proposes to bring the city back to its eighteenth-century appearance" (Samonà et al. 1965). The illustrative report of 15 typewritten pages, ${ }^{3}$ which leaves no doubts as to the proposal's radical nature, precisely outlines the system of infrastructural nodes at the foundation of a new large-scale territorial framework for Venice consisting of its lagoon hinterland.

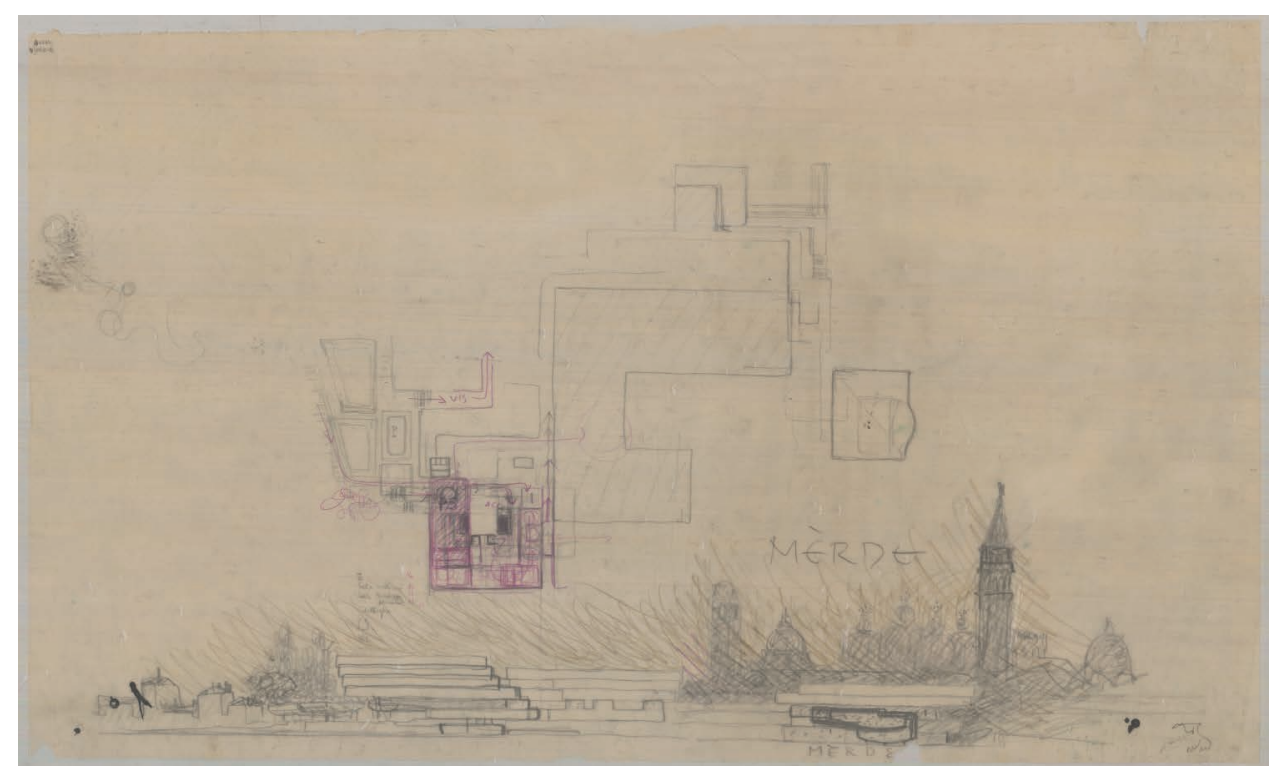

FIGURE 10.3 Romano Chirivi, Costantino Dardi, Emilio Mattioni, Valeriano Pastor, Luciano Semerani, Giorgio Zecchi (health consultant), New Civil Hospital of Venice, Motto: Tadzio, study design, plan, and side elevation, 1963; copy from the Projects Archive - IUAV University of Venice,. Projects Archive Collection. 


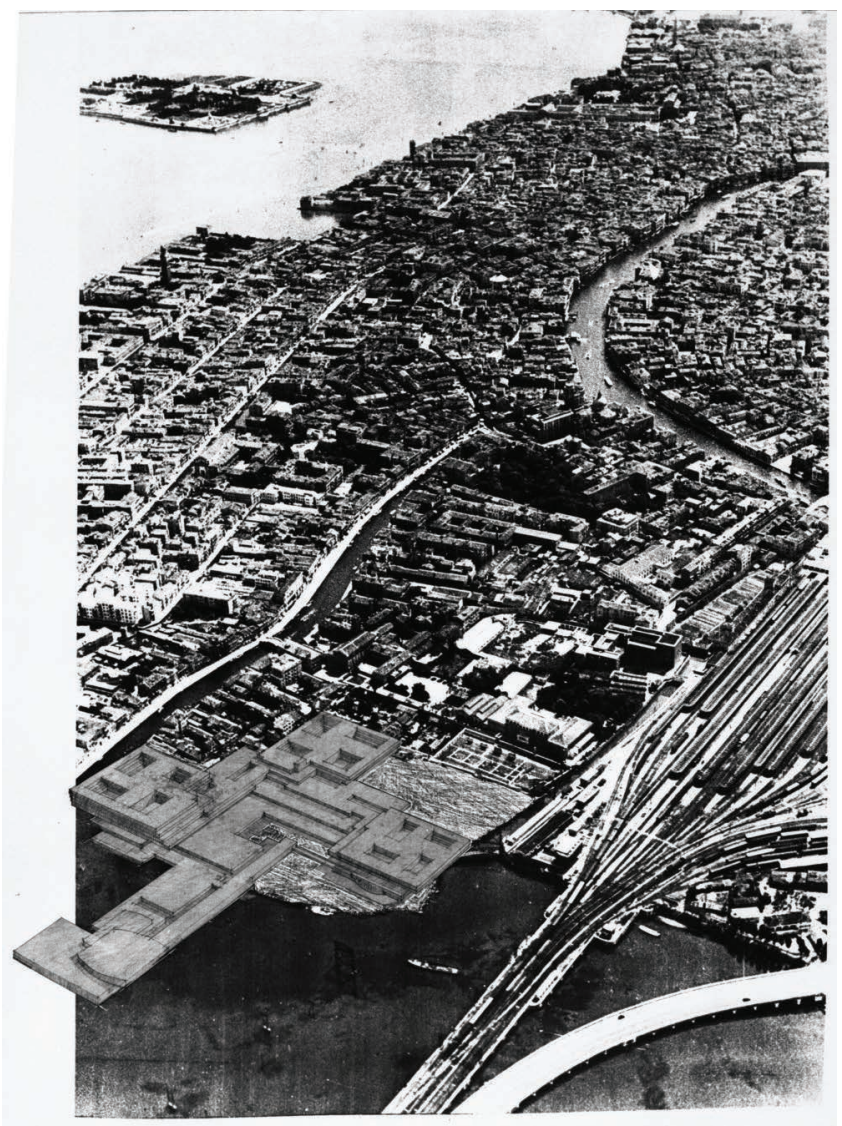

FIGURE 10.4 Romano Chirivi, Costantino Dardi, Emilio Mattioni, Valeriano Pastor, Luciano Semerani, Giorgio Zecchi (health consultant), New Civil Hospital of Venice, Motto: Tadzio, photomontage from a bird's eye view, 1963; copy from the Projects Archive - IUAV University of Venice, Projects Archive Collection.

The urban restructuring table highlights the shape and position of the new parts of the city: the two large islands/building and the convent of Santa Chiara, restored to its original insular nature, define a water space antimetric to St. Mark's basin which is configured as a new urban gateway to the mainland (Figure 10.6).

The definition of this "precise western front involves a large excavation in the Campo di Marte area in addition to the suppression of part of the docks of the Maritime Station Basin" (Samonà et al. 1964, 7), consistent with a "new interpretation of the city as a system of compact nuclei alternating with empty spaces of a conservative nature" (Samonà et al. 1964, 9).

Large parts of the dying urban fabric are physically abraded from the map because "in a first approximation, the interruption of growth would then coincide with an act of emptying the superfetation areas where [...] the 'growth itself' occurs, indeed with pathological aspects" (Samonà et al. 1964, 7).

In fact, the design envisages "the 'stripping' of the borders of Venice" (Tentori 1994, 46). Egle Renata Trincanato had unsuccessfully tried to moderate this emptying: 


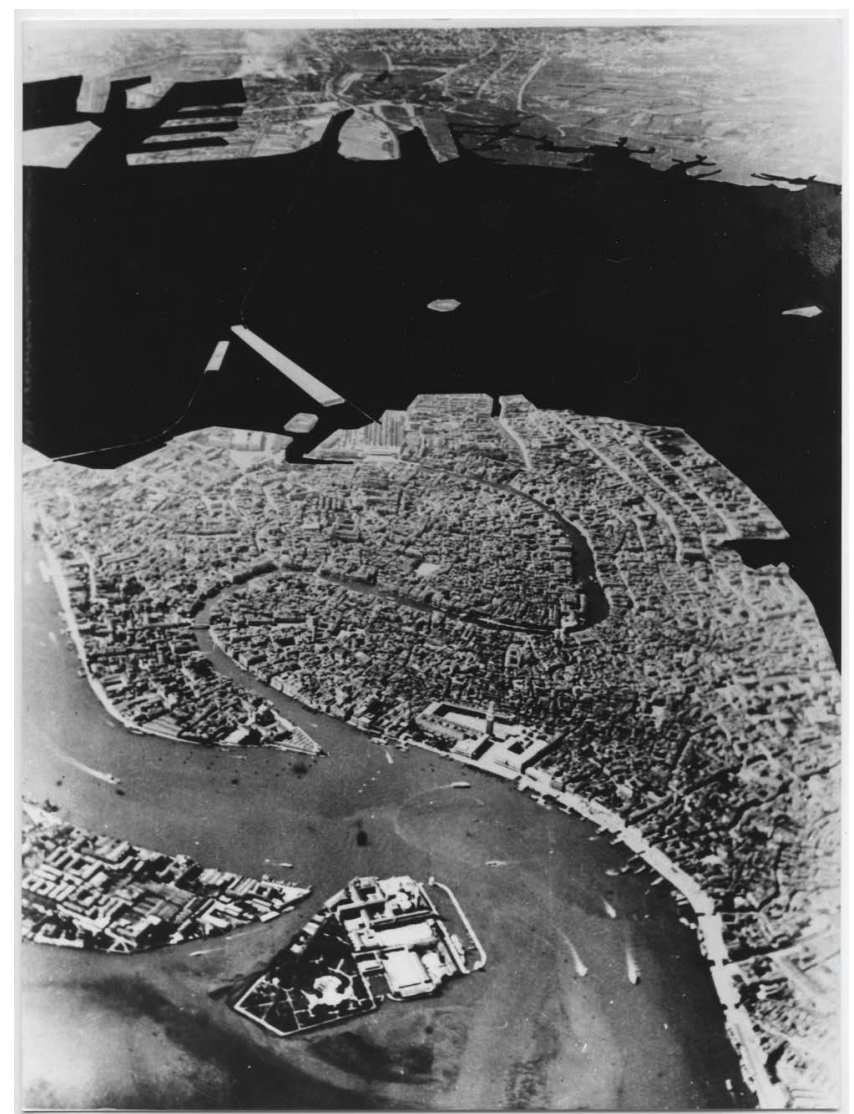

FIGURE 10.5 Giuseppe Samonà, Costantino Dardi, Emilio Mattioni, Valeriano Pastor, Gianugo Polesello, Alberto Samonà, Luciano Semerani, Gigetta Tamaro, Egle Renata Trincanato, Novissime: international competition for drafting the urban and volumetric plan for Nuovo Tronchetto Venice, 1964. Aerial view toward west with the new basin of Santa Chiara, photomontage, Projects Archive - IUAV University of Venice, Alberto, and Giuseppe Samonà collection.

especially Gigetta Tamaro Semerani, [...] was so enthusiastic about this proposal [...] that she would not have been satisfied with returning to the eighteenth-century profile, defined in the map by Lodovico Ughi, but would have liked to go back to the outline of the de' Barbari plan!

(Tentori 1994, 46)

In the final draft, the project envisaged the excavation of over 700,000 square meters of emerged land and the emptying of over 250,000 square meters of insular soil from "superfetation and [...] incongruous sedimentation" (Samonà et al. 1964, 11). Near the present bridgehead, "all the post-eighteenth century incrustations" (Sammartini 1964) are canceled. The "well-founded urban theory" (Rossi 1964, 4) that guided the scalpel and the bulldozer of NOVISSIME drew scientific sustenance precisely in that "series of studies and attempts [...] which find an important centre in the University of Venice" (Rossi 1964, 4). A 


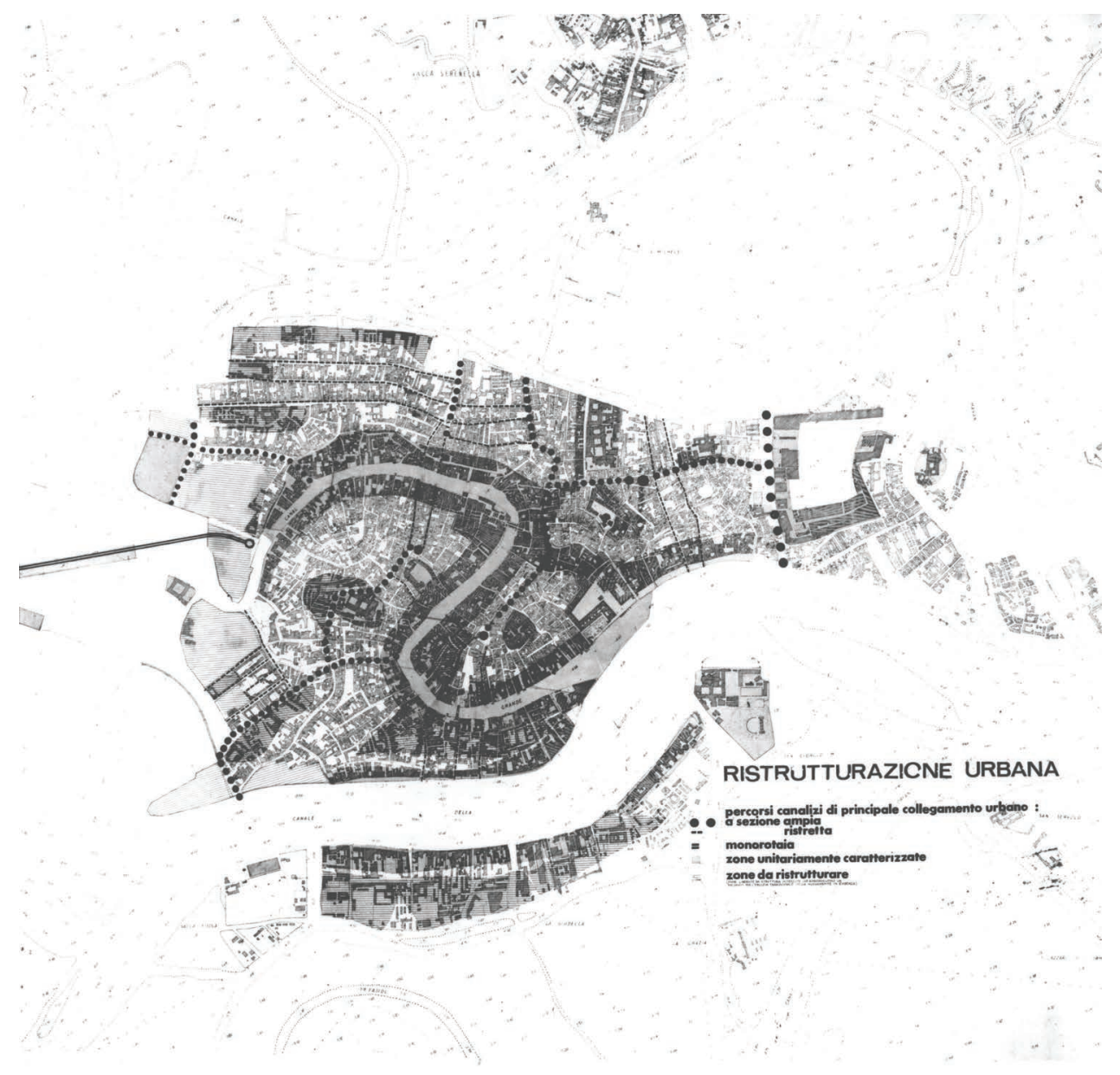

FIGURE 10.6 Giuseppe Samonà, Costantino Dardi, Emilio Mattioni, Valeriano Pastor, Gianugo Polesello, Alberto Samonà, Luciano Semerani, Gigetta Tamaro, Egle Renata Trincanato, Novissime: international competition for drafting the urban and volumetric plan for Nuovo Tronchetto Venice, 1964. Project table: "Urban Restructuring," Projects Archive - IUAV University of Venice, Alberto and Giuseppe Samonà Collection.

very well-defined position emerges from the design report that places the urban analysis at the base of a judgment on the different constituent parts of the city, attributing to the emptiness, like the new architectures, the role of specifying the function and character of the existing city (in a manner as provocative as it was prophetic if referred to our present time), identifying a "genealogy" of urban studies and compositional research destined to spread and develop in the years to come.

And if from the historiographical point of view, "Whether there is an ideal fil rouge connecting Samonà and Trincanato to subsequent developments is a question to be demonstrated [...]" (Zucconi and Carraro 2011, 16), it is a fact that - as Aldo Rossi later wrote starting from L'urbanistica e l'avvenire della città negli stati europei [Urban Planning and the 
Future of the City in the European States] by Giuseppe Samonà, the studies on architecture would find their foundation in the

city seen for the first time in its entirety, [...] in its continuous line of evolution; [...] The city [will become] a fact, and a fact of such importance that it will have to be constantly reckoned with; also and above all from the point of view of architecture.

(Rossi 1968, 135-136)

\section{The Theory of the City by Parts}

In many ways, Giuseppe Samonà's book would sanction this "urban" connotation of architectural design, attempting to critically establish a bridge between the methodological/ typological and functionalist/parametric approach of the Modern Movement with the problems of reconstruction and the new in the Italian and European city.

The objective of investigating "how the foundations of a theory of the city can be the foundations of a new architecture" (Rossi 1968, 136) is the underlying theme of the series of lectures on the Theory of architectural design (Samonà 1968) promoted by Giuseppe Samonà at IUAV in the winter of 1966, which compares the positions of "eight scholars" on the subject: Guido Canella, Mario Coppa, Vittorio Gregotti, Aldo Rossi, Alberto Samonà, Gabriele Scimemi, Luciano Semerani, and Manfredo Tafuri.

Some pairs of words, repeated like a mantra until consumption - analysis and design, typology and morphology, city and context - from the research initiated by Carlo Aymonino and Aldo Rossi on building typology and urban morphology (Distributive characters of buildings course, 1964/1965) to the 1969 publication of the Gruppo Architettura ${ }^{4}$ Architectural Theses (Gruppo Architettura 1969) represent the basis of a familiar lexicon destined to spread even outside the narrow Venetian circle as a distinctive element of a certain scientific approach to architecture starting from a theory of the city by parts.

The second of the Gruppo Architettura Design Papers (Gruppo Architettura 1970), dedicated to the National Competition of Ideas for the Detailed Plan of the Historic Center of Trieste, in the proposals presented by the groups of Gianugo Polesello, motto D2, and Luciano Semerani, motto GIOVANNA, and urban studies and "emptiness" (Marras 2019, 2) return to operate as tools of architectural and urban composition in the city by parts.

The Gruppo Architettura, in many ways an interference that originated from the collision of two entities - the duo of Aymonino and Rossi and the Samonà system, consisting of the maestro and his direct and indirect students - will explode in that sort of diversified archipelago that was IUAV starting from the end of the 1970s and in a kaleidoscope of poetic visions attributable to individuals.

A "School of Venice" (Semerani 1985) ante litteram in the summer of 1978, at the end of Carlo Aymonino's direction, once again placed Venice at the center of attention and called architects from European and American schools (Raimund Abraham, Peter Eisenman, John Heduk, Rafael Moneo, Bernard Hoesli, Oswald Mathias Ungers) to design the island of San Giobbe in West Cannaregio.

In the 10 images for Venice on display, subsequently collected in the catalogue (Aymonino et al. 1980), the scientific instruments of the School emerged in the projects of the "Venetians" (Carlo Aymonino, Gianugo Polesello, Aldo Rossi, Luciano Semerani), and for many lines passed through, by reaction, the designs of the "outsiders," contributing to the dissemination 
of a sort of Venice paradigm in which a scientific approach to the design of the city by parts and poetic incandescence of the images that can change its face, between mark and word, are the essential aspects of a heritage to be recognized and asserted.

\section{Notes}

1 Romano Chirivi (group leader), Costantino Dardi, Emilio Mattioni, Valeriano Pastor, Luciano Semerani, Giorgio Zecchi (health consultant); after ups and downs, in 1964 Le Corbusier was commissioned to draw up a feasibility study in the same area covered by the competition.

2 Giuseppe Samonà with Costantino Dardi, Valeriano Pastor, Gianugo Polesello, Alberto Samonà, Luciano Semerani, Gigetta Tamaro, Egle Renata Trincanato.

3 The Illustrative Report of NOVISSIME is fully published and translated by the author (Marras 2019-1).

4 Carlo Aymonino, Romeo Ballardini, Guido Canella, Costantino Dardi, Gianni Fabbri, Mauro Lena, Pierluigi Nicolin, Raffaele Panella, Gianugo Polesello, and Luciano Semerani, with different appearances deferred over time.

5 Giovanni Marras, "Il valore del vuoto. Gianugo Polesello nel Gruppo Architettura," in AA.VV., Gianugo Polesello. Un maestro del Novecento. La composizione in architettura, Lettera Ventidue Edizioni, Syracuse, pp. 92-103.

\section{Bibliography}

Aymonino, C. and V. Pastor, F. Dal Co et al. 1980. 10 immagini per Venezia, ed. F. Dal Co. Roma: Officina Edizioni.

Gruppo Architettura. 1969. Per una Ricerca di progettazione 1. Tesi di Architettura. Venezia: IUAV.

Gruppo Architettura. 1970. Quaderni di Progettazione 2. 4 Progetti per il centro storico. Venezia: IUAV.

Marras, G. 2019-1. NOVISSIME. Radicalismo inverso: il vuoto come valore, gli studi urbani come strumento. VESPER. 1: 170-185.

Marras, G. 2019-2. Il valore del vuoto. Gianugo Polesello nel Gruppo Architettura. In Gianugo Polesello. Un maestro del Novecento. La composizione in architettura, eds. A. Dal Fabbro, P. Grandinetti, 92-103. Siracusa: Lettera Ventidue Edizioni.

Monestiroli, A. 1997. L'architettura secondo Gardella. Bari: Laterza.

Muratori, S. 1960. Studi per una operante storia urbana di Venezia. Roma: Istituto Poligrafico dello Stato.

Piccinato, L., G. Samonà, G. Astengo, et al. 1965. Concorso per un Quartiere residenziale CEP in Venezia-Mestre, Barene di San Giuliano. Architettura, cronache e storia, VI: 169.

Rossi, A. 1964. Considerazioni sul Concorso internazionale per la redazione del piano urbanistico planivolumetrico per la nuova sacca del Tronchetto a Venezia. Casabella. 293: 2-17.

Rossi, A. 1968. Architettura per I musei. In Teoria della progettazione architettonica, ed. G. Samonà, 122-137. Bari: Edizioni Dedalo.

Sammartini, T. 1964. Venice: Tronchetto Island international competition. Architectural Design. 12: 594.

Samonà, G. 1946. Inauguration of the 1945-46 Academic Year, at the University of Architecture of Venice. YEARBOOK. Academic Years 1943-44, 1944-45, 1945-46. Venezia: Tipografia Emiliana.

Samonà, G. 1950. Inauguration of the 1948-49 Academic Year, at the University of Architecture of Venice. YEARBOOK. Academic Years 1948-49, 1949-50. Venezia: Tipografia Emiliana.

Samonà, G., G. Polesello, L. Semerani, et al. 1964. International Competition for Drafting the Urban and Volumetric Plan for Nuova Sacca del Tronchetto. Illustrative report. Venezia: IUAV - Archivio Progetti, Trincanato Collection.

Samonà, G., G. Polesello, L. Semerani, et al. 1965. Concorso per la sistemazione dell'isola del Tronchetto a Venezia. Architettura Cronache e Storia. 111: 602-603.

Samonà, G., G. Canella, M. Tafuri, et al. 1968. Teoria della progettazione architettonica, ed. G. Samonà. Bari: Edizioni Dedalo. 
Samonà, G. 1970. Caratteri morfologici del Sistema architettonico di Piazza San Marco. In Piazza San Marco, l'architettura, la storia, le funzioni, ed. G. Samonà: 6-18. Padova: Marsilio.

Samonà, G. 1973 (I ed. 1934). La casa popolare degli anni '30. Venezia: Marsilio.

Samonà, G. 1978. Necessità di uno studio di Venezia per la pianificazione urbanistica delle sue esigenze moderne. In G. Samonà, L'unità architettura urbanistica. Scritti e progetti 1929-1973, ed. P. Lovero, 240-249. Milano: Franco Angeli.

Semerani, L. 1985. The School of Venice. AD. Architectural Design. Monographic issue.

Tentori, F. 1994. Imparare da Venezia. Bari: Laterza.

Trincanato, E. R. 1948. Venezia Minore. Milano: Edizioni del Milione.

Trincanato, E. R. 1997. Sull'insegnamento di Giuseppe Samonà. In Su Venezia e la laguna Veneta e altri scritti di architettura 1948-1993, ed. F. Tentori, 447-449. Roma: Officina Edizioni.

Zucconi, G. and M. Carraro. 2011. Officina IUAV, 1925-1980. Saggi sulla scuola di architettura di Venezia. Venezia: Marsilio. 